\title{
Undervisning, læring og teknologi under Corona-pandemien
}

\author{
Introduktion til Læring og Medier (LOM) nr. 24, 2021
}

\author{
Inger-Marie F. Christensen, Syddansk Universitet \\ Christian Dalsgaard, Aarhus Universitet \\ Marianne Georgsen, UCN \\ Roland Hachmann, UC SYD
}

\section{Indledning}

I marts 2020 blev alle undervisnings- og uddannelsesinstitutioner med meget kort varsel fysisk lukket ned. På få dage skulle al undervisning, vejledning og eksamen omdannes fra fysiske og blendede læringsrum til helt digitale læringsrum. Begrebet "nødundervisning” er i denne sammenhæng blevet brugt som betegnelse for, at undervisningen og de didaktiske rammer hurtigt skulle omlægges i krisesituationen. Dette resulterede i, at undervisere og studerende mange steder var sat under pres, da undervisningen hurtigt skulle genplanlægges ud fra de metoder og ressourcer, herunder teknologier, der umiddelbart var tilgængelige. I perioden opstod en lang række nye læringsdesigns og praksisser, der afspejlede denne hurtige digitalisering, og mange undervisere fik et øget indblik i online undervisning og i muligheder og begrænsninger ved digitale teknologier.

Der er allerede foretaget en lang række undersøgelser af, hvorledes Covid-19-nedlukningen har haft indflydelse på undervisningen på danske uddannelsesinstitutioner (Andersen, Gerwien, \& Kammer, 2020; Danmarks Evalueringsinstitut, 2020; Georgsen \& Qvortrup, 2021; Misfeldt et al., 2020; Rambøll, 2020; Zambach, Franck, Nielsen, \& Kjærgaard, 2020), og hvorledes disse erfaringer fra perioden kan kvalificere og være katalysator for både organisatorisk og didaktisk udvikling (Jensen, Hedelund, \& Mortensen, 2021; Madsen, Gottfredsen, \& Noer, 2020).

Dette temanummer af LOM bidrager ligeledes med viden og erfaringer fra nedlukningen, men frem for overordnede evalueringer og perspektiver dykker temanummeret ned i specifikke tematikker af særlig forskningsmæssig interesse. Der peges på forskellige områder, hvor den hurtige digitalisering har haft indflydelse på underviseres og studerendes digitale kompetencer, undervisningens tilrettelæggelse samt praksisformer og deltagelsesroller i onlinefællesskaber. Temanummerets artikler udfolder blandt andet forandringer i vejleder- og underviserroller, der kræver en gentænkning af tilstedeværelsesformer og belyser hvilke aktiviteter, der understøtter en mere hybrid eller fuld onlinedeltagelse i evaluerings- og eksamensformer. Heri ligger blandt andet en mere procesorienteret tilgang til vejledning, andre måder at løse faglige opgaver på og alternativer til den lærerstyrrede undervisning.

Det er værd at bemærke, at der i forbindelse med gentænkning af undervisning under nedlukningen er udviklet nye, digitalt understøttede praksisser, der viser sig at understøtte de studerendes læring bedre end hidtidig praksis og samtidig bidrager til en bedre udnyttelse af de tilgængelige læringsrum. Fælles for disse eksempler er, at den traditionelle undervisning ikke blot er overført til online-formatet men er transformeret, så de(t) tilgængelige læringsrum udnyttes på hensigtsmæssig vis. Eksempelvis illustreres det i en af temanummerets artikler, hvordan undervisning i og demonstration af praktiske færdigheder kan lægges ud som videoer, som de studerende kan anvende i deres forberedelse, hvilket giver bedre tid til træning af praktiske færdigheder i professionslokalet. Også i forbindelse med fremmedsprogsundervisningen i grundskolen er nye effektive, digitalt understøttede praksisser dukket op. F.eks. lyd- 
og videofiler som afleveringsformat, der ikke bare gør eleverne mere trygge ved at øve sig på fremmedsproget, men også giver lærerne et effektivt redskab til evaluering af og feedback på elevernes læring.

Især online vejledning fremhæves som vellykket, da onlineformatet giver nye muligheder så som fælles orientering mod og synkron samskrivning af tekst via skærmdeling og lettere adgang til vejleder, der i højere grad bliver en del af processen og mere smidigt kan inddrages efter behov.

Da fysisk fremmøde igen var muligt efter nedlukningen var det med pladskrav og deraf følgende begrænsninger $\mathrm{i}$ det fysiske rum, hvilket gav anledning til eksperimenter med hybride undervisningsformater. Særligt hybride forelæsninger viste et vist potentiale sammenlignet med forelæsningen som webinar, viser en af temanummerets artikler. Hybride forelæsninger, hvor en emoderator faciliterer onlinedeltagelse, muliggør underviserens multimodale formidling og giver onlinedeltagerne adgang til spørgsmål og svar onsite, samtidig sørger e-moderatoren for, at onlinedeltagerne kan få svar på deres spørgsmål.

Flere artikler i temanummeret peger således på, at nedlukningen har tvunget undervisere til at afprøve forskellige nye, digitalt understøttede praksisser, hvilket dels har ført til innovative undervisningsdesigns, der også vil blive benyttet fremover, og dels har skærpet undervisernes viden om, hvordan digitale værktøjer kan eller ikke kan understøtte læring, undervisning og vejledning. Dog byder de nye, digitalt understøttede praksisser også på udfordringer, f.eks. når det viser sig, at negative og positive holdninger til mundtlige, online eksamener hviler på personlige præferencer og værdier frem for det synkrone, online læringsrums muligheder og begrænsninger og/eller digitale kompetencer. Hvordan kan sådanne opdagelser kvalificere udviklingen fremadrettet, og er det ønskeligt i højere grad at give de lærende valgfrihed med hensyn til lærings-/eksamensrum?

Et helt centralt perspektiv der går på tværs af artiklerne er spørgsmålet om udnyttelsen af de kompetencer som både studerende, undervisere, vejledere og andre aktører anvender eller må erhverve sig for at kunne deltage effektivt i onlinefællesskaber. På den ene side synes der at være en grundlæggende positiv tilgang til de nye praksis- og aktivitetsformer, men samtidig kræver disse genforhandlinger af roller, identiteter, rutiner og meningsskabelse. Temanummerets artikler viser, at tidligere erfaringer hos undervisere og studerende spiller en afgørende rolle både i forhold til det at kunne deltage i digitale undervisningsmiljøer men også i forhold til at kunne gennemskue, hvordan form og indhold i aktiviteterne understøttes, så de giver bedst mulig mening i forhold til uddannelsernes mål. Ligeledes er underviserens frigivelse af en del af kontrollen over hvordan og med hvilke redskaber, der skal læres, et vigtigt element i vellykket gentænkning af undervisning. Slippes elever og studerende løs og gives de frihed til selv at vælge digitale værktøjer, understøttes kreativitet, interaktion og samskabelse. Dog tyder noget på, at det kan være svært for nye studerende at finde hinanden og interagere online, mens ældre studerende klarer sig bedre. Dette understreger betydningen af at udvikle et socialt og fagligt fællesskab face-to-face som bagtæppe for succesfuld onlinedeltagelse.

\section{Temanummerets artikler}

LOM \#24 indeholder to artikler udgivet uden for tema. Det er Digital fabrikation for unge $i$ specialtilbud af Jacob Davidsen, Henrik Søndergaard og Anne Marie Kanstrup samt Four phases of video streaming: A case study of medical teaching af Mads Ronald Dahl, Kasper Lauritzen og Peter Musaeus. Nedenfor præsenteres artiklerne i temanummeret.

I artiklen Undervisning i praktisk færdighedsudøvelse i en digital tid undersøger Lyngsø, Møller og Jensen gennem semistrukturerede kvalitative interviews hvordan undervisere på sundhedsuddannelserne ved de danske professionshøjskoler, i lyset af den digitale transformation af undervisningen, der pågik under Covid-19-nedlukningen, oplevede specifikke undervisningselementer, 
f.eks. brugen af video, som egnede eller uegnede i forhold til praktisk færdighedsudøvelse. Forfatterne konkluderer, at videoer af praktisk færdighedsudøvelse er egnet til visualisering af pensum og demonstration, og at inddragelsen af disse ville kunne give anledning til et fokusskifte i det fysiske rum, hvor kropslig læring i virkelighedstro kontekster kan understøtte begyndende indtagelse af professionelle roller.

I artiklen Online oral examinations during Covid-19 undersøger Graf, Rasmussen og Ruge studerendes og underviseres erfaringer med online, mundtlige eksamener på dansk på en professionshøjskole. Studiet består af kvantitative statistiske analyser på baggrund af en spørgeskemaundersøgelse og kvalitative analyser af åbne svarkategorier. Analytisk er forfatterne særligt optaget af teknologiske, følelsesmæssige, dialogiske og forberedelsesperspektiver hos de undersøgte. Artiklen konkluderer i overensstemmelse med andre studier, at både studerende og undervisere slår positivt ud på disse kategorier, på trods af øvrige negative holdninger til nødundervisningen. Forfatterne viser dog, at den overordnede positive tilgang afspejler en opfattelse af, at prøveformen afspejler den undervisningsform, der har domineret perioden. Går man mere detaljeret til værks, understreger forfatterne, ligger der ligeledes en række udfordringer i relation til forholdet mellem et positivt blik på formen og det faglige udbytte.

Artiklen Digitalt understøttet projektbaseret vejlederpraksis fokuserer på, hvordan og i hvor høj grad digital transformation af vejlederpraksis understøtter og udfordrer den projektbaserede vejledning. Metodisk baseres artiklen på interviews med undervisere og studerende, hvor der spørges ind til erfaringer med digital projektvejledning under Covid-19-nedlukningen. Konnerup, Bertel og Larsen peger på baggrund af undersøgelsen på, at nedlukningen har medført en nytænkning af vejledningen i forhold til hybride muligheder. Det konkluderes, at der viser sig en række potentialer i forhold til fleksibilitet, øget studentercentrering, og at den digitalt understøttede vejledning går fra at være overvejende produktorienteret til mere procesorienteret.

Med afsæt i en tematisk analyse af 52 svenske gymnasielæreres personlige beretninger om overgangen til fjernundervisning i foråret 2020 kaster artiklen The teacher as innovator during a pandemic: Changing practices and culture lys over de vilkår og praksisser, der understøttede, hindrede eller generelt opstod i forbindelse med overgangen. Lindberg og Haglind anvender en narrativ tilgang og interesserer sig teoretisk for praksisser i bevægelse og understøttelse af emergerende praksisser. Analysen afslører 3 overordnede praksisser som værende vitale for arbejdet med at udvikle fjernundervisning, nemlig kollaborative, kommunikative og kreative praksisser. Sidstnævnte, de kreative praksisser, fremanalyseres som resultatet af de to førstnævnte praksisser. Sammen kan de 3 praksisser give optimale betingelser for umiddelbar pædagogisk innovation samt fremadrettet transformation af undervisningspraksisser i digitale og socio-tekniske kontekster til fremme af kvaliteten af undervisning og læring.

Artiklen Sproglærererfaringer fra skolenedlukningen i foråret 2020 af Christensen, Nissen og Gustenhoff sætter fokus på, hvordan fremmedsprogsundervisningen i grundskolen både blev udfordret og udviklet under Covid-19-nedlukningen. Survey-data og uddybende interviews med sproglærere viser, at skoledagens skemalagte struktur, identifikation af teknologi til understøttelse af elevernes sprogtilegnelse såvel som klasserumsledelse og relationsarbejde blev udfordret. Imidlertid viser undersøgelsen, at der også er opstået nye mundtlighedspraksisser, som kan kvalificere fremmedsprogsdidaktikken fremadrettet. Digitale teknologier kan øge elevernes motivation for og interaktion på målsproget samt åbne op for nye evaluerings- og feedbackpraksisser.

I artiklen Problembaseret læring under en pandemi: Erfaringer med digitalt understøttede læringsaktiviteter i en nedlukningstid bidrager Lyngdorf, Bertel, Andersen og Ryberg med viden om og perspektiver på, hvordan digital transformation kan understøtte aktiv og kollaborativ læring i deltagerstyrede læringsmiljøer. Datamaterialet er indsamlet i efteråret 2020 og udgøres af fokusgruppeinterviews med undervisere og studerende fra Aalborg Universitet. Via en tematisk analyse 
vises, hvordan strategier for digitalt understøttet læring er blevet oplevet og har udviklet sig fra nødundervisningen i foråret 2020 til parallelle og hybride tilgange i efteråret 2020. Artiklen konkluderer, at digital teknologi tilbyder nye læringsrum med nye dynamikker, som både studerende og undervisere skal blive fortrolige med, finde vej og udvikle nye praksisser i. Forfatterne peger på at især den aktive læring har været udfordret, og at der er behov for en organisatorisk indsats for at sikre en bred implementering af praksisser for, hvordan fysiske og digitale rum mest hensigtsmæssigt kombineres i hybride modeller til understøttelse af aktive læreprocesser.

I artiklen Blended Learning - frem mod en ny normal på ungdomsuddannelserne præsenterer LundLarsen, Jørgensen og Andresen resultaterne af en undersøgelse af erfaringer med undervisning under Covid-19-nedlukningen blandt lærere på ungdomsuddannelserne. Undersøgelsen har fokus på, hvordan lærerne har udviklet og gentænkt deres undervisning, og artiklen peger på en række områder, hvor lærerne forventer at fortsætte med nye undervisningsformer, når situationen normaliseres. Blandt andet peger artiklen især på alternativer til lærerstyret undervisning og nye former for vejledning og differentieret undervisning som områder, lærerne kan indarbejde i fremtidige blended learning-forløb.

I artiklen Coronapandemiens indflydelse på universitetsadjunkters holdning til teknologi $i$ undervisningen undersøger Mikkel Godsk universitetsadjunkters ændrede holdning til teknologi i undervisningen, og diskuterer hvorvidt det med sandsynlighed kan tilskrives coronapandemiens erfaringer. Gennem analyse af fire enslydende spørgeskemaundersøgelser blandt samtlige teknisknaturvidenskabelige deltagere $(\mathrm{N}=66)$ i Aarhus Universitets adjunkt-pædagogikum umiddelbart ét år før og ét år efter pandemiens udbrud identificeres fire temaer i signifikante ændringer i deltagernes holdning til teknologi i undervisningen. Undersøgelsen viser en generelt og signifikant øget, positiv holdning til teknologi i undervisningen og interesse i de elementer, der omhandler pædagogiske metoder og modeller, teknologiens potentiale og rolle samt brugen af videokonference og video. Endvidere er der en signifikant øget interesse i vidensdeling med kolleger og pædagogisk support. Undersøgelsen peger på et stort aktuelt potentiale for undervisningsudvikling og pædagogisk kompetenceudvikling i brug af teknologi på universiteterne, da de holdningsmæssige barrierer blandt undervisere, der før blev anset for vanskelige at overkomme, måske er ved at nedbrydes.

Meyer og Henningsen beskæftiger sig i artiklen Praksisforløb under covid-19: cand.it studerende og digital omstilling i praksis med, hvordan nedlukningen har påvirket de studerendes måder at deltage i praksis på uden for universitetet, f.eks. feltarbejde og praksisophold i virksomheder. Artiklen undersøger bl.a., hvor de studerende har særlige faglige forudsætninger for at bidrage til omlægning og udvikling af virksomhedens aktiviteter til digitale praksisser. Data peger på, at de studerendes faglighed involveres i håndtering af både sociale afkoblinger og centrale digitale omstillingsprocesser i virksomhederne, og at dette kan forme deres faglighed såvel som virksomhedernes praksis.

I artiklen Hvad kan HyFlex-organiseret undervisning? - de studerendes tilgang sætter Mathiasen og Bregnhøj fokus på kommunikationens betingelser i hybrid, fleksibel undervisning (HyFlexundervisning), hvor halvdelen af de studerende på skift kan møde op på campus, mens resten kan følge undervisningen live, online. En e-moderator i forelæsningslokalet fungerer som et kommunikativt bindeled mellem onlinedeltagerne og forelæser. Artiklens empiri omfatter en kvantitativ og kvalitativ del og har fokus på forelæsninger og de studerendes kommunikative deltagelse. Undersøgelsesresultaterne fortæller bl.a., at $74 \%$ af de studerende vælger at følge forelæsningerne online, og at de studerende er enige om, at HyFlex er en god og fleksibel forelæsningsorganisering. Argumenterne for valg af onsite/online-deltagelse viser en vifte af individuelle præferencer.

\section{Et blik mod horisonten}

Hvordan kommer vi videre fra nødundervisningen? På mange af landets uddannelsesinstitutioner ser vi en række forskellige tiltag som opfølgning på erfaringerne fra nødundervisningen under Covid-19- 
nedlukningerne. Der er i høj grad kommet et øget fokus på at udvikle undervisning og uddannelser, der baserer sig helt eller delvist på online aktiviteter. Måske er det vigtigste spørgsmål ikke, om undervisningen og uddannelser skal være online eller face-to-face, eller hvad blandingsforholdet skal være mellem de to former. Ud fra artiklerne i dette temanummer er et centralt spørgsmål nok nærmere, hvordan online undervisning kan tilrettelægges, og hvor styrkerne i online aktiviteter er. Det har nødundervisningen ikke givet alle svarene på.

Artiklerne i dette temanummer viser en række eksempler, der udnytter online muligheder til at udvikle nye undervisningspraksisser, der ændrer ved og udvikler eksisterende undervisning - og ikke alene gør det samme i et online format, som vi før gjorde i hinandens fysiske nærvær. Generelt peger artiklerne ikke på at erstatte face-to-face-undervisning, men nærmere på at udvikle undervisning. Og dette arbejde er vi ikke i mål med endnu. Den tilrettelagte nødundervisning har været præget af et markant tidspres, da undervisningen bogstaveligt talt fra den ene dag til den anden overgik til at foregå hjemmefra og dermed online.

Der var derfor på forhånd god grund til at antage, at den praktiserede, online undervisning ikke med det samme ville leve op til alle tænkelige kvalitetskrav eller opfylde alle underviseres og studerendes ønsker til god undervisning - for slet ikke at tale om egentlige bidrag til videreudvikling af online og blended undervisning på institutionerne. Dette bekræftes også i et vist omfang af de undersøgelser, der er lavet i Danmark. Artiklerne i dette nummer viser imidlertid, at der også er gjort mange positive erfaringer med online undervisning, og alene det omfattende erfaringsgrundlag, institutioner og undervisere har med digitalt understøttet undervisning fra nødundervisningen, er et unikt afsæt for videre arbejde. Der er således god fornuft $\mathrm{i}$ at arbejde videre med målrettet at eksperimentere med og udvikle online aktiviteter i undervisningen, eksempelvis med afsæt i et eller flere af de relevante områder som beskrives i artiklerne i dette temanummer.

Et andet væsentligt forhold, som erfaringerne fra nedlukningen har mindet os om, er, at det kræver specifikke kompetencer både at tilrettelægge, gennemføre og deltage i online undervisning og læring, og at man ikke kan tage for givet, at disse kompetencer er til stede. Såvel artikler i dette nummer som de tidligere nævnte undersøgelser nævner underviserens kompetencer som et centralt forhold i den videre udvikling af digitalt understøttet undervisning.

De fleste uddannelsesinstitutioner har længe haft fokus på digitale kompetencer som et element i deres underviseres faglighed. På trods heraf har covid-19 periodens erfaringer bekræftet os i, at kompetenceniveauet er ujævnt, og kompetenceudviklingsbehovene varierede. Der er stadig behov for at fokusere på betjeningskompetence for nogle underviseres vedkommende, ligesom behovet for flere kompetencer til redidaktisering i forbindelse med omlægning af undervisning er tydeligt. Begge dele er noget, der kan varetages lokalt på institutionerne, og også i vidt omfang har eksisteret som tilbud, også før nedlukningen. Flere artikler og undersøgelser peger imidlertid på, at fraværet af absolut nødvendighed har afholdt mange fra at opsøge disse tilbud tidligere. Endvidere er der noget, der tyder på, at studerendes brug af digitale medier og teknologier ikke i tilstrækkelig grad bliver omsat i forbindelse med undervisning. Georgsen \& Qvortrup (2021) beretter således om det forhold, at de studerende i høj grad forstår sig selv som teknologisk kompetente i forhold til at deltage i online undervisning. Samtidig er de frustrerede over kvaliteten af både undervisning og læring, hvilket kan ses som udtryk for, at teknologisk betjeningskompetence ikke er tilstrækkeligt.

Lyngdorf m.fl. og Lindberg \& Haglind skriver i dette nummer om kommunikative og kollaborative kompetencer som centrale for både undervisere og studerende, ligesom der er behov for at fokusere på studerendes muligheder og motivation for at tage aktivt ansvar for egen læring (hvilket understøttes af data fra Georgsen \& Qvortrup 2021, jf. ovenfor). Spørgsmålet om digitale kompetencer er således mere aktuelt end nogensinde, og det nuværende, relativt ensartede erfaringsgrundlag for store grupper af både studerende og undervisere virker som et oplagt afsæt for at arbejde mere målrettet med denne vigtige opgave. 


\section{Hvad blev vi ikke klogere på?}

Det store spørgsmål herfra er, hvordan vi kommer videre fra nødundervisningen og frem mod en fastholdelse af de gode erfaringer fra covid-19-nedlukningen i den fremtidige onlineundervisning? Som skitseret ovenfor, og beskrevet i detaljer i temanummerets artikler, er der mange gode, men ofte enkeltstående erfaringer, som har fundet og vil finde vej ind i tilstedeværelsesundervisningen, mens vi må vente lidt endnu før de større organisatoriske og institutionelle udviklinger bliver tydelige.

Langt hovedparten af de studier og undersøgelser af onlineundervisning under covid-19-nedlukningen, som er publiceret på nuværende tidspunkt, er baseret på data fra 2020. De siger noget om oplevelser og erfaringer, som er kendetegnet ved at være i frisk erindring; ved at være personlige / individuelle; ved at fokusere primært på deltagernes egen enten undervisning eller læring; og endelig ved at være data indsamlet over en relativt kort periode. Det er således for tidligt at sige noget om hvilke varige forandringer, covid-19-nedlukningen eventuelt fører til på vores institutioner, på uddannelserne og i undervisningen. I de hidtil publicerede undersøgelser har der været relativt lidt fokus på den organisatoriske og ledelsesmæssige dimension, om end vi ved, at denne har stor betydning for muligheden for at lave institutionelt forankret uddannelsesudvikling. Efter genåbningen af institutionerne i 2021 har vi set, at nedlukningens erfaringer har ført til en skarpere adskillelse mellem onlineundervisning og fysisk tilstedeværelse, noget der måske kan tilskrives et behov for hurtigt at vende tilbage til det 'normale'. Det betyder imidlertid, at diskussioner af potentialer i at arbejde online eller blended med integration af forskellige modus er gledet i baggrunden.

Ovenstående indikerer, at der stadig er et uudforsket læringspotentiale i covid-19-periodens erfaringer med onlineundervisning, hvor især det længere perspektiv bliver interessant at følge.

\section{Referencer}

Andersen, M. H., Gerwien, R. G., \& Kammer, A. (2020). Sammen, hver for sig: universitetsstuderendes læringsstrategier under COVID19-nedlukningen. Læring og Medier, (23), 1-18.

Danmarks Evalueringsinstitut. (2020). Studerendes oplevelse af online undervisning på første semester. Hentet fra: https://www.eva.dk/videregaaende-uddannelse/studerendes-oplevelse-onlineundervisning-paa-foerste-semester

Georgsen, M., \& Qvortrup, A. (2021). Erfaringer og oplevelser med online undervisning på 9 videregående uddannelsesinstitutioner i foråret 2020. Hentet fra: https://www.ucviden.dk/ws/portalfiles/portal/124345447/COVID_19_undervisning_resume_final.pdf

Jensen, C. S., Hedelund, M., \& Mortensen, C. L. (2021). Vi ses på skærmen - en undersøgelse af studerendes perspektiver på online undervisning.

https://ipaper.ipapercms.dk/ErhvervsakademiAarhus/Forskningsrapportguides/vi-ses-paa-skaermen/?page=1

Madsen, P. H., Gottfredsen, R., \& Noer, V. R. (2020). Digital didaktik med Covid-19 som anledning:

Anbefalinger til fortsat udvikling af digitale didaktikker i VIA. Hentet fra:

https://www.ucviden.dk/ws/portalfiles/portal/113031620/Indsats 1.10 Rapport december 2020.pdf

Misfeldt, M., Jensen, L. X., Hvillum, N. P., Harboe, T., Lindvig, K., Ejrnæs, M., Larsen, L. N.

(2020). Evaluering af online-nødundervisning forår 2020. Hentet fra:

https://curis.ku.dk/portal/da/publications/evaluering-af-onlinenoedundervisning-foraar-2020(f5625373oadf-4815-9762-6183fo2b739f).html

Rambøll. (2020). Undersøgelse af online undervisning og eksamen. Forår 2020. Hentet fra: https://newsroom.au.dk/fileadmin/Artikler/AU Kommunikation-

Medier/Kommunikation/Undersoegelse_af_online_undervisning_og_eksamen_foraar_2020_191020.pdf 
Zambach, S., Franck, M., Nielsen, M.M., \& Kjærgaard, A. (2020). Survey of educators' and students' experiences during the COVID-19 lockdown. Hentet fra: https://teach.cbs.dk/wp-

content/uploads/ShortDescHomePageV2.pdf

\section{Forfattere}

\section{Inger-Marie F. Christensen}

Ph.d.-studerende

Institut for Design og Kommunikation, Syddansk Universitet

imc@sdu.dk

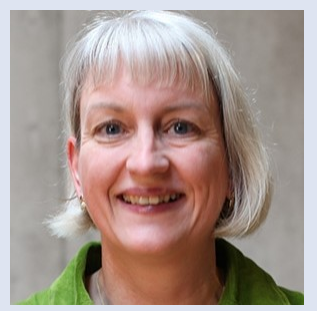

\section{Christian Dalsgaard}

Lektor

DPU, Aarhus Universitet

cdalsgaard@edu.au.dk

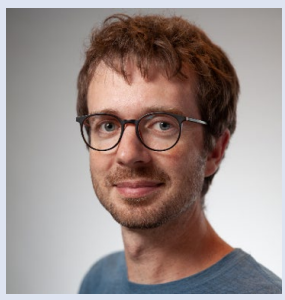

\section{Marianne Georgsen}

Docent

Program for Professionsudvikling og Uddannelsesforskning, UCN

mage@ucn.dk

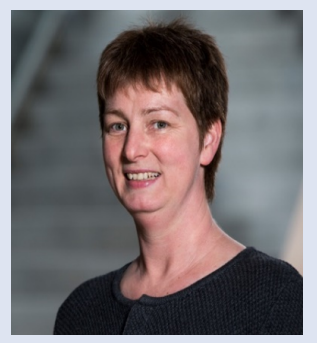

\section{Roland Hachmann}

Lektor, Postdoc

Forskning, UC SYD

rhac@ucsyd.dk

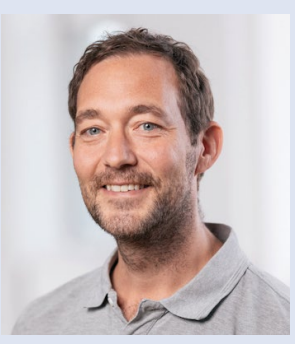

